\title{
Scenes of Mongoose as a Predator in the Papyrus Thicket During the Old Kingdom
}

Abdallah Mohammed Diab*

Higher Institute of Tourism and Hotels (EGOTH), Ismailia, Egypt

ARTICLE INFO

Keywords:

Mongoose

Papyrus Thicket

Fishing

Fowling

Predator

Birds

Attack.

\begin{abstract}
This paper studies the mongoose (ichneumon) as a predator widely represented in the fowling and fishing scenes, chasing birds in a papyrus thicket. From the predynastic period, several scholars attempted to attest the mongoose among other animals prevailed at this time, which had been called different names in ancient Egyptian language. It also deals with specific features of mongoose in order to differentiate it from other similar animals such as Otter and Weasel. The paper reviews many tomb scenes of the mongoose as a predator of young birds in their nests, with several scenes, causing the belief that the ancient Egyptian trying to tame it. Besides, it discusses the unrealistic appearance of the papyrus thicket in which the animals were preyed, as a fictional rather than a true reflection of wildlife. furthermore, the religious meaning interpreted these scenes. Especially, all related scenes were found in a funerary context and therefore one expects them to have a religious dimension, even though this was not explicitly stated.
\end{abstract}

(C)2020 Faculty of Tourism and Hotels, Fayoum University All rights reserved

\section{Introduction}

The Egyptian mongoose is widely distributed in Africa. In Egypt, it lives principally in Lower Egypt and Fayoum, preferably near water and swims well. its diet includes various smaller animals and fruits. From its enmity to serpents, was looked upon by the Egyptians with great respect (Wendorff, et al. 2001: 621; Wilkinson, 1871: 229).

From Predynastic Period, several scholars attest the mongoose among other animals prevailed at this time. From the Gerzean Period (Naqada II), the mongoose (ichneumon) may be attested on pottery. The animals painted on the sides of the buff-colored pottery vase cannot be a certainty but are likely to be Egyptian Mongoose (fig. 1). where the connection between the wavy lines on the lower part of the vessel as snakes, and the well-earned reputation of the mongoose for destroying serpents. (Houlihan, 1996: fig.85). Another white-lined jar, from Naqada (fig. 2), shows the lower animal, by the length of the curve of the tail, must be a mongoose, with the bristly hair being represented upright (Petrie, 1920: Pl. XVIII. 67, P. 15). Furthermore, on a tall alabaster cylinder jar dated back to the early dynasties, with an inscription in high relief, bearing the name of Den, and an animal running up a 身sign (fig. 3), it looks like a mongoose, as Gardiner and Petrie suggest, in particular, that the legs are not those of either a cat or a panther (Gardiner, 1938: p. 89; Petrie, 1901: pl.VII.7).

Scenes featuring pursuits in the papyrus marshes of the Delta are frequently found in the tombs of the ancient Egyptians, as a large-scale scene where the tomb owner himself is spearing fish and catching birds with a throw-stick, known as scenes of fishing and fowling.

\footnotetext{
${ }^{*}$ Contact Abdallah Mohammed Diab at: amdiabf@gmail.com
} 
These scenes are included in all tomb's decoration from the Old Kingdom to the late period (Binder, 2000: 111). All scenes featuring mongoose as a predator, a popular theme shows the tomb owner boating in the marshland against a backdrop of papyrus plants, among which small mammalian predators search for prey and throngs of birds' care for their young. Sitting in stylized, bowl-shaped nests perched precariously on top of papyrus flowers, the birds of different species can be seen crouching over their eggs to protect them from the predators (BailleulLesuer, 2012: 94).

\section{Previous studies}

The mongoose plays an important role in ancient Egyptian religion; therefore, previous studies show the role of this animal in Egyptian religion. A paper by Cooney studied the statue of a mongoose as a sacred animal (Cooney, 1965). Another study of BrunnerTraut, concentrate on the role of mongoose in Egyptian religion (Brunner-Traut, 2001). Two studies conducted by Roeder (Roeder,1936), about mongoose in religion and art, the other by Brunner-Traut about the shrew and mongoose as animals of the sun god (Brunner-Traut, 1965). Furthermore, there was a study that shows the difference between Otters and mongoose (Evans, 2010). The current research about mongooses is focused on his role as a predator in the fowling and fishing scenes in the papyrus thicket and the composition of these scenes with its meaning in a religious context.

\section{Name}

The name of mongoose in Greek, ichneumon, means literally 'the tracker' and is closely connected with the word ixos meaning 'track' or 'footstep.' (Cooney, 1965: 103). Several names of mongoose have been found in the ancient Egyptian language, for example, \&ळी hts which has a varied meaning 'a ratlike animal' (Wb. III, 204 (13), 'a weasel,' or 'shrewmouse' (Budge, 1920: 522), and sometimes called a 'desert mouse' (Hannig, 1997: 572). The mongoose was also known as "Pharaoh's rat" (Cooney, 1965; 101), due to the close similarity between the two animals and the mongoose. A stone block found in the $5^{\text {th }}$ dynasty solar sanctuary of king Sahure at Abusir (fig. 4), showed the same animal \&ळl hts. Bissing described it as mongoose like h3trw (Bissing, 1955: p. 331, Pl. XXIII). Once more, it appeared as a title of an official called Kha-BauSeker in his tomb at Saqqara ( $3^{\text {rd }}$ Dynasty) (no.3073) where he was personified by mongoose
hts rn wr 'the great name ichneumon or mongoose' (fig. 5A), it was regarded by Sethe as mongoose, judging by the determinative. (Murray, and Sethe: P. 11, Pls. I, II). The only example that was known where the king is personified by an ichneumon or a mongoose trampling an enemy, belonging to Amenhotep III, on a sealing discovered at the palace of el-Malqata (Bertrand, 1982: 269), the inscription shows a mongoose crushing unknown enemies it reads "Nb-mt-re, the mongoose" (victorious) over (his) enemies." (Hayes, 1951: 167) (fig. 5B).

The other following names belong to the animal but as a deity in the afterlife. The widely known word was h3trw base of a statue in Berlin, on two sides of the base the king is described as 'beloved of' a deity; one deity is named ' $m$ ' $m$, and the other h3trw. These words were studied by Brunner-Traut; she believed that h3trw like ' $\underline{d}$ designated the mongoose. (Brunner-Traut, 2001: 149; Wassell, 199:86, 98; Budge, 1920: 534; Hannig, 2000: 657; Wb III, 236, 10; Bunson, 2012: 196), and also $\theta$ f $९$ h htrw found on an inscription in the tomb of Ramesses VI at Thebes (Waugh, 1995: 343), Coptic Saywl, qatoul (Černy, 1976: 238).

The uncertainty and generalization were clear in some

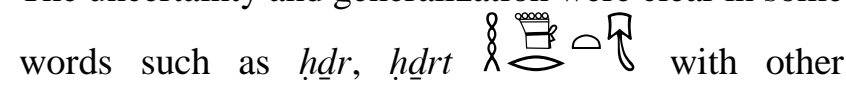
determinative rat-like animal and translated by Hannig as a wolf (Hannig, 1997: 576), a mammal (WB III, p.214. 11-12), or a mongoose (?) (Budge, 1920: 524), Furthermore was known as 'an animal' (Wb 1, 186, 10-11), $=-10$

$\Longleftarrow \Longleftarrow \varlimsup^{\mp}$ ' $m$ ' $m$ 'the eater of the dead' (Budge, 1920;120). In the latter the word has a specific determinative, Griffith described it thus: 'The determinative is an animal with short legs, tail slanting outwards and downwards, the head unfortunately lost. It may be the mongoose or a rat'. Comparing ' $m$ 'swallow' with the mongoose's swallowing of its prey, snakes, and maybe ${ }^{\mathrm{C}} \mathrm{m} \mathrm{m} \mathrm{m}$ and the h3trw indicate that it was a similar animal (Wassell, 1991: 86-88). A word such as 'hm $\rightleftharpoons$ है translated as a 'mongoose' (ichneumon) (Wb I, 225. 4), while the same word ○ hm, translated by Faulkner it as 'voracious (?) spirit' in the afterlife (Faulkner, 1964: 
48), although, the determinative representing the mongoose.

\section{The mongoose Features.}

The Egyptian mongoose (Herpettes ichneumon), Modern colloquial 'Nems' belongs to the family of the Herpestidae whose members have non-retractable claws (Lewise and Llewellyn-Jones, 2018: 385; Hoath, 2009: 89). The form of mongoose was much elongated and weasel-like, it has very short legs, a rounded short ear, scarcely appearing above the fur, with a very long tail, much tapered, and a long black hair at the end. A very harsh and straight coat, and a long flat skull, with a very short facial portion (fig. 6) (Anderson, 1902: 191). The Egyptian mongoose length was 90.9-106.8; tail 36.3-46 cm; weight 1.9-4.0kg (Hoath, 2009: 89; Evans, 2016: 221; Lewise and Llewellyn-Jones, 2018: 385; Description de 1' Égypte, vol. 1, pl. 6). Generally, its body-color was dark and the face rather darker (Anderson, 1902: 190- 191; Hoath, 2009: 89). The mongoose in the chapel of Idout (T 86) has long, fine brushstrokes of a darker color to indicate the hair on the brown back. The body color of this animal seems to be from dark brown to buff on the under-parts (Smith, 1946: 269). This animal inhabits dense vegetation, such as rainforests and reed beds, or shrubby terrain, usually near watercourses, or rocky hills, where it hunts for a range of prey (Arnold, 1995: 39; Hoath, 2009: 89; Evans, 2016: 221). The mongoose diet varied between small mammals, birds, reptiles, including snakes, frogs, toads, eggs, fish, large insects, fruits (Hoath, 2009: 90). Mongoose is fearless, friendly little animals and easily tamed, and would probably be well-known to the Egyptians since the Old Kingdom ((Murray, 1905: 42). It has a catlike gliding motion along the papyrus stem where he is frequently depicted (Murray, 1937: 25). These animals are renowned for their ability to attack and kill snakes (Evans, 2000: 80).

The mongoose appears frequently in Egyptian art, although it can be confused by the artist with similar animals like the shrew, weasel, otter, and genet (Lewise and Llewellyn-Jones, 2018: 385). There are close similarities between the mongoose and weasel, but the Egyptian weasel is much smaller, slenderer with short, brown hair. The tail is proportionately shorter and shorter-haired towards the base. (Hoath, 2009: 90). Due to poor preservation of painted details, the use of unnatural colors, and the incorrect or imprecise rendering of some physical features have occasionally hampered the identification of particular species depicted in Egyptian wall scenes. (Evans, 2007: 245)

\section{The papyrus thicket}

One of the most familiar of Egyptian tombs' scenes is the tomb owner fishing and fowling in the marshes, attested as early as the Fourth Dynasty (Binder 2000: 111). During the New Kingdom. The fishing and fowling scene is strictly symmetrical, where the tomb owner represented twice in the same mural scene performing fishing and fowling (Manniche, L., 1989: 35). A marsh in Ancient Egyptian language was called idhw was called $d y t 7440$ d sts papyrus-marsh, or $3 \mathrm{~h}$ in $\theta$ 部

480; $\mathrm{Wb}$ I, 15 different species of birds that are flying or nesting: and the predator such as an Egyptian mongoose frequently tried to snatch young birds from a nest and in return are attacked by the parents (Kanawati, 2009: 72). The plant itself is tall, green, and leafless, the plant has a sloping root as thick as a man's arm, and tapers gracefully up with triangular sides to a length of not more than about $5 \mathrm{~cm}$ or more in height, ending in umbel, or flower head (Nicholson, and Shaw, 2000; 229; Hepper, 1990: 33). The landscape was a scene set in the papyrus swamp, teeming with the plant, insect, and birdlife. The thicket is shown of various breadths and heights (Binder, 2000: 114).

These birds are shown in various states of alarm due not only to the human hunter but also, in many tombs' scenes, to the presence of mongooses and genets that raid nests to devour fledglings and eggs. Some of the birds are depicted flying above the thicket in the apparent disorder; some are shown attacking the mongooses and genets by pecking them, while others are represented sitting upon their nests with their eggs below them in an unusual posture (fig.7), with their wings held out in front of their bodies. (BailleulLesuer, 2012: 49; Epron-wild, 1953: pl. 119)

\section{Scene of mongoose attack}

The Egyptian mongoose is customarily portrayed stealthily creeping up on bird's nest, usually filled with a clutch of eggs or frantic fledglings; the panicked parents often swoop down in a vain attempt to drive off the mongoose and sometimes the young are pictured being violently take off from the nest and quickly devoured. This is entirely consistent with the predatory behavior of this agile water-side dweller, as 
mongoose regularly consume birds and their eggs (Houlihan, 1996: 125-126; Smith, 1949: 178). Generally, the main theme on the papyrus thicket is the mongoose attacking the birds' nest.

The usual scenes show the deceased on a skiff, before a heavy papyrus thicket, many birds hover above the papyrus umbel, while a mongoose creeping on a papyrus stalk to attack the nest. (Brovarsky, 2000: fig. 26, 42). The attacking mongoose snatched helpless birds or fledglings in their nests. Once the mongoose attacks, the tail is aroused or becomes bushy (Cooney, 1965: 105). In a behavior known as "mobbing," the adult birds fly about the predators, swirling and diving at them to make them retreat. Swooping dangerously close to their enemies, the birds are depicting pecking at the ears, eyes, backs, and tails of animals, and scratching their muzzles with their feet, accurately reproducing the defensive behavior of wild birds (Bailleul-Lesuer, 2012: 94-95)

In the $4^{\text {th }}$ dynasty or later tomb of Neb-em-Akhet (LG 86) at Giza, various birds are perching on the umbels of a papyrus-thicket, to the right and left sides of the thicket are two mongooses, each climbing a bending stem of papyrus to reach a nest built upon it. The nest to the right-hand seems to contain young birds, and the distressed mother-bird is shown frantically flapping its wings above the head of the mongoose in a vain effort to drive it away (Hassan, 1943: 135, fig. 77). A similar scene of mongoose attacking birds in the papyrus thicket represented in another $4^{\text {th }}$ dynasty tomb of $\mathrm{Li}$ Nefert (no. 25) at Giza (Schürmann, 1983: 35, fig. 6a$6 b)$. In another scene from the $5^{\text {th }}$ dynasty tomb of Senedjemib Inti (G 2370) at Giza, a mongoose and a genet attack the nests in a papyrus thicket, as usual, and a mother defend her young birds from the creeping mongoose on a papyrus stem (Brovarsky, 2000: fig.26, 42). In the $5^{\text {th }}$ dynasty tomb of Pthotep and Akhethetep (no. 64) at Saqqara, a scene in the chapel of Pthotep, shows a papyrus thicket dens with birds, the mongoose preys on a young bird after causing a panic in the nest, while an adult bird maybe a mother trying to save it (fig. 8). Meanwhile, a similar scene is shown in the chapel of Akhethetep, where a mongoose facing three young birds in their nest with a papyrus stalk bent under his weight, while two birds attack him (fig.9) (Davies, 1901: pls. XIII, XIV).

In the tomb of Iasen ( $\mathrm{G}$ 2196) at Giza, which dates back to the $5^{\text {th }}$ dynasty, shows the deceased fowling in the marsh on a skiff, and a mongoose creeping on a bent papyrus stalk to snatch a little bird from the nest (fig.10) (Simpson, 1980: Fig.30). A fishing and harpooning scene from the $5^{\text {th }}$ dynasty tomb of $\mathrm{Ti}$ (no.60) at Saqqara (fig.11), shows one mongoose approached a nest that was protected by birds flying close to the nest (Epron-wild, 1953: Tf. 119; Murray, and Sethe, 1937:Pl. II), also, a fishing scene in the tomb of Shedu at Deshasheh dates back to the $5^{\text {th }}$ dynasty, depicts two mongooses attacking two nests simultaneously while a bird is trying to protect his nest by knocking the mongoose in the head (Petrie, 1898: Pl. XXII). Another repeated scene of the attacking mongoose in the $5^{\text {th }}$ dynasty tomb of Urarna (no.25) at Sheikh Said (Davies, 1901:pl. xi). A double scene of fishing and fowling in $5^{\text {th }}$ Dynasty tomb of Neferiretenef (fig.12), from Brussels Musée Royaux (E.2465), represents a creeping mongoose approaching a nest while, an adult bird attacked it when it has reached its nest (Binder, 2000: fig. 11. 7). In a limestone relief depicted in fine composition, at the Vatican museum at Rome, dates back to the $5^{\text {th }}$ dynasty shows a mongoose, a cat, and a genet (fig.13). The three animals attacking simultaneously the three bird's nests. The decisive difference lies in the wide distance between the papyrus perennials from each other, making the thicket more spacious and airier that of the Old Kingdom. (Wolf, 1957: fig. 688). Other two mongoose from the $5^{\text {th }}$ dynasty tomb of $K^{\mathrm{C}}-\underline{d} w^{\mathrm{c}}$ (T 32) at Giza, are shown climbing upon a bending papyrus stalk, intending to rob bird's nest. (Hassan, 1950: 99. fig.80).

A double scene of fishing and fowling in the $6^{\text {th }}$ dynasty tomb of Ka-m-Ankh (G 4561) at Giza, shows a mongoose is preparing to attack in a papyrus thicket (Junker, J., 1940: Abb. 8a). Another $6^{\text {th }}$ dynasty tomb of Qar (G7101) at Giza, with a Fragment of wall relief, showing a mongoose climbing branch of papyrus (toward the right) with foliage background from a hunting or fishing scene (Simpson, 1976: 14, fig. 16), and the 6th dynasty tomb of Idout (T 86), at Saqqara, a mongoose, climbs along the stems in search of a prey (fig.14). The birds, startled, fly away from all sides while others protecting their young (or sometimes eggs) by putting their wings before them. (Macramallah, 1935: 16. Pls. VII, XXVIII). A fowling in the marsh scene dates back to the 6th dynasty tomb of Pepi-ankh (no.2) at Meir, shows the tomb owner ridding a papyrus skiff, and a mongoose creeping up in a papyrus stalk to attack the nests, at the same time a pied kingfisher and another bird attacked them to defend their nest. Another scene from the previous tomb, shows the deceased again fishing, while a mongoose creeps up a papyrus stem, in search of a prey (Blackman, \& Apted,1953a: Pls. XXIV, XXVIII; Binder, 2000: figs. 11.8-11.9). 
Nikauisesi depicted on a boat, in his $6^{\text {th }}$ dynasty tomb (T59b) at Saqqara fowling in a papyrus thicket (fig. 15). The top of the thicket before him ends in three rows of open umbels, above which birds are flying. to the left are depicted a partly damaged bird nesting, below which an Egyptian goose is setting on its eggs and a pair of Pied Kingfishers attacked an Egyptian Mongoose which has reached their nest and caught one of the fledglings. To the right is an Egyptian goose sitting on eggs, while a similar bird is attacking an Egyptian Mongoose which has already caught a large goose. (Kanawati, and Abder-Raziq: 2000: 39-40, Pl. 50 ). A fishing scene in the $6^{\text {th }}$ dynasty tomb of Hesi ( $T$ 59a) at Saqqara, this scene was divided by a mound of water. On the right a mongoose snatched a bird, while it seems his fledglings are safe in their nest, flying over them an adult bird (fig.16) (Binder, 2000: fig. 11.17). A scene from the $6^{\text {th }}$ dynasty tomb of Seankhuiptah at Saqqara (fig. 17), shows two Egyptian Mongooses have climbed the stems and snatched birds or fledglings in their nests. The two adult birds fly about the predators and the mongoose which has reached their nest and caught one of the fledglings (Kanawati, and Abder-Raziq: 1998, pl. 76). An unusual scene in Mereruka's mastaba (T 57A) shows a small mammal in a water-side haunt devouring a fish. it could be an Egyptian mongoose lunching on one of its favorite food (Houlihan, 1996: 127; Tristant, \& Ryan Ellen, 2017: fig.1), this behavior is accurately portrayed by Egyptian artisan of a mongoose eating a fish (fig. 18) (Kanawati, \& woods, 2009: 72, fig.157-158; The Sakkarah Expedition,1938: Pls. 128-129; Evans: 2010: 124).

The representation of mongoose launched its attack on birds' nest continued during the middle and new Kingdom, but not in a large scale and less in detail. For example, in the 12th dynasty tomb chapel of Ukhhotpe (C no.1) at Meir, the thicket itself is alive with birds and other creatures, including a couple of mongooses, which are climbing up the papyrus-stalks with an aim to rob the nests (Blackman, \& Apted, 1953b: 25, Pl. XIII). A fishing scene in the $12^{\text {th }}$ dynasty tomb of Khnumhotep (no. 3) at Beni Hasan, above a mound of water a mongoose and a genet preparing to attack (fig. 19), this time above the papyrus umbels, (Newberry, 1893a: Pl. XXXIV). Another double scene of fishing and fowling represented in the $12^{\text {th }}$ dynasty tomb of Hesuwer at Kom el-Hisn shows the creeping mongoose on a stem and a bird defending its nest (Binder, 2000: fig. 11.18). In the $18^{\text {th }}$ dynasty tomb (no.73) belongs to overseer of the cattle of Amun in the region of Hatshepsut, at Sheikh Abd el Qurnah, a double scene of fishing and fowling, shown a mongoose between the papyrus thicket preparing to launch its attack (Säve-Söderbergh, 1957: Pl. VII), also a fragment of limestone block from the tomb of Neferhotep (TTA5) at Thebes, now in the Louver Museum (fig.20). This $18^{\text {th }}$ dynasty scene, shows birds flying away from a clump of papyrus, disturbed by both a genet and a mongoose that is threatening their nests. The fresh colors and the liveliness of the scene reflect the painter's skill (Musée du Louver).

\section{Taming the Mongoose}

Mongoose has not been domesticated but can be tamed (Jackson, 2018: 23). Example of the later is found in the $5^{\text {th }}$ dynasty tomb of Ptahhetep and Akhethetep (D 64) at Saqqara, in the part of a hunting scene (fig. 21), a gazelle lies under a bush, an ichneumon in the herbage maybe waiting to hunt (Davies, 1900a, b: P. 10, Pl. XXII; Strandberg, 2009: 77). Two Old Kingdom scenes show mongooses being held by their tails as men lower them into the waters of the Nile, suggesting that tamed mongooses could have been used to flush out birds from papyrus thickets during the hunt (Lewis, and Llewellyn-jones, 2018: 385). The scene from the $6^{\text {th }}$ Dynasty tomb-chapel of the vizier of Mereruka (T 57A) at Saqqara, portrays a man in a Papyrus raft grasping the tail of a very large mongoose, as it climbs a Papyrus stem to catch a group of fledgling's birds (fig.22). The precise interpretation of this scene, however, remains quite elusive, and it cannot be used to demonstrate that mongooses were somehow trained as Houlihan stated (Houlihan, 1996: 127, Pl. X; The Sakkarah expedition, I, 1938: Pl.19; Kanawati, \& woods, 2009: 71, Pl. 145), The only other similar scene is found in the $6^{\text {th }}$ Dynasty tomb of Mehu (T 59). Both these tombs are at Saqqara, although the first is located in the Teti cemetery and the second in that of Wenis (fig.23) (Lashine, 2011: 102; Kanawati, $\&$ woods, 2009: 71, Pl. 146). Because of this unusual scene, some scholars have offered this as evidence that mongoose was tamed to hunt for their owners (Evans, 2000: 80; Vernus, \& Yoyotte, 2005: 612). There are, however, slight differences between the two scenes: Mereruka's attendant is shown in a separate boat in front of him and is catching the mongoose by the tip of its tail, while Mehu's attendant is depicted in front of him in the same boat and is seizing the animal from the upper part of its tail (Lashine, 2011: 102), causing two ducks to fly upward. It seems likely that these images depict animals that are under the control of the hunters and, some scholars suggested the mongoose has been sent into the adjacent papyrus thickets to rush 
birds for the tomb-owner to hunt with his throw-stick (Evans, 2016: 224).

The earliest Old Kingdom scene usually show the mongoose marauding. The two represented occur in fishing and fowling scenes in which the principal figures are human hunters, but there is nothing in the rest of the scene to indicate that the mongoose is not hunting entirely by itself. (Hinton and Dunn, 1967: 87, fig. 18). It seems improbable that mongoose could be trained to the chase, but it is represented in hunting scenes on the water at various periods of Egyptians history (Rice, 2006: 81). Vernus and Yoyotte suggest that holding ichneumon by the tail in swampy thickets is to direct it to the chosen prey, which means the ichneumon was controlled (Vernus and Yoyotte, 2005: 335). The tamed Egyptian mongooses have been known to be kept as much valued household ratcatchers and destroyers of snakes, but despite some persistent claims to the contrary, there is no firm evidence for this practice in the pharaonic time (Houlihan, 1996: 127).

In the $11^{\text {th }}$ Dynasty tomb of Baqet I (no. 29), at Beni Hasan, a scene where five men carrying weapons for hunting and fighting (fig. 24), the third man is led by a leash a mongoose, a dog is beside it. Newberry uncertain over the identity of the animal (Newberry, 1893b: 34, Pl. XXX; Vernus, \& Yoyotte, 2005: 612; Porter, and Moss, 1968: 160). Whether this animal is described by others as an Egyptian mongoose (Herpestes ichneumon) or a domestic dog (Canis familiaris). Confusion has arisen over its identity because although it resembles a wild mongoose, the creature is leashed and wears a collar. The inevitable conclusion that the mongoose must also be used as an assistant to hunters, as he was a part of the hunting scene (Evans, 2016: 221-223, Evans, 2000: 80; Newberry, 1893: Pl. XXX).

\section{Composition of Scenes}

During the Old Kingdom, the composition of the papyrus thicket varied only of detail, such as the introduction of a wild cat also attacking a nest near the mongoose. As a commonplace incident of their landscape, the Egyptians continued this composition through the Middle Kingdom, where the detail of the mongoose devouring a bird seems to have been introduced, and later in tomb paintings of the New Kingdom. It is particularly frequent in Theban paintings of the $18^{\text {th }}$ Dynasty (fig.13) (Cooney, 1965: 104).

The ancient Egyptian artisans depend mainly on a real element (a papyrus, birds, mongooses, genets, mammals, and other creatures) when they try to buildup a papyrus landscape, but with unreal representation in nature. The number of reliefs and paintings representing the mongoose in its destructive aspects. it appears in Egyptian reliefs of the Old Kingdom and later, where it is seen high up on a sharply bent papyrus stalk due to its weight, it is about to attack a nest of eggs or very young birds, with the mother bird hovering in alarm above the scene (Wolf, 1957: 229; Cooney, 1965: 104).

These small predators appear frequently in marsh scenes in which they hunt for young birds. In every example, they advance towards their prey by climbing a papyrus stem. The mongoose is often imaginatively rendered climbing up a thin, fragile papyrus stalk that merely bends due to its weight. These particular details are, quite imaginative, and purely the product of artistic skills since under no circumstances could a slender papyrus stem support the weight of a living mongoose (or even a cat which was introduced later as a predator in the scene of the papyrus thicket). Also, the frequently pied kingfisher which is repeatedly depicted defending its fledglings from the attacking mongoose, both of these species' nests in cliffs' holes or riverbanks or earth caves? could any real bird's nest balance on such a thin stem (Houlihan, 1996: 125-126; Wolf, 1957: 229; Evans, 2008: 1662) for example, in the $5^{\text {th }}$ Dynasty sun temple of Niuserre at Abu Gurob a pied kingfisher is portrayed sitting on a nest in a tree. These nature observations are entirely fanciful, because the pied Kingfisher's mode of setting is nothing like this at all, as it drills a deep hole into banks of rivers and canals and places its eggs in an expanded chamber at the rear of the tunnel (Houlihan, 1986: 115-116).

The reason for this abnormality in Egyptian art remains unclear, but perhaps an explanation can be found in the practical difficulties of attempting to render the birds nesting in a burrow (Houlihan, 1986; pp115-116). It can be seen that even a picture like this is ultimately from the imagination (Wolf, 1957: 229) However, a crucial detail that has been completely overlooked is that Egyptian mongooses are strictly terrestrial and do not climb (Evans, 2008: 1662). A limestone slab of a swamp relief from the mortuary temple of Neuserre illustrates how this function of the papyrus umbel even represented on relief. On this slab, an unopened papyrus head supports a nest of fledglings (fig. 25), although, one umbel may contain two or three hundred main rays of umbel (Kantor, 1999: 12, 53, fig. II.9), which are incapable of supporting a nest with fledglings. The scenes of 
fowling and fishing, both of these activities are shown taking place in the marshes. Everything suggests that these scenes are fictional rather than a true reflection of reality. (Malek, 2000:129).

The banana-like shape of the nests, which attacked by mongoose, is unknown before the $18^{\text {th }}$ Dynasty, in the Old Kingdom these nests are flat and without curvature. It was clear as a determinative when referring to the word of the nest. Gardiner sign-list (G

48) $s \check{s}$ "nest" in the marsh. Sometimes takes the place of 2007: 473; Lambert, 1925: 351), and was pronounced by Faulkenr as š̌y (Faulkner, 2002: 246), it pronounced also as $\stackrel{2283}{\sigma} \mathrm{I}$ šy in Late Egyptian as 'a nest in the marsh' (Lesko, and Lesko, 2004: 79). From the Middle Kingdom, this form continues, along with form of basket-shape, having a flat top and curved under the section. Another $18^{\text {th }}$ dynasty detail is the placing of the eggs, which stand gracefully leaning against nothing, in contrast with the earlier stacking of these items. The symmetrical placing and drawing of papyri blossoms and buds in a neat form, formal rows was a development of the $18^{\text {th }}$ Dynasty tombs at Thebes. (Cooney, 1965: 104-105). The following table show the position of the nest in regard to mongoose and the place of nest on the papyrus stem.

\section{Table 1}

Position of the mongoose and the place of the nest on the papyrus stem.

\begin{tabular}{|c|c|c|c|c|c|c|c|}
\hline \multirow{2}{*}{ Tomb } & \multirow{2}{*}{ dynasty } & location & \multicolumn{2}{c|}{$\begin{array}{c}\text { Position of the nest to } \\
\text { the mongoose }\end{array}$} & \multicolumn{2}{c|}{ places of the nest on the papyrus stem } \\
\hline & & & $\begin{array}{c}\text { Before } \\
\text { it }\end{array}$ & $\begin{array}{c}\text { Above } \\
\text { it }\end{array}$ & $\begin{array}{c}\text { Below } \\
\text { it }\end{array}$ & $\begin{array}{c}\text { On the same papyrus } \\
\text { stemwith mongoose }\end{array}$ & $\begin{array}{c}\text { On another } \\
\text { papyrus stem }\end{array}$ \\
\hline Senedjemib Inti & 5 & Giza & & $\checkmark$ & & $\checkmark$ & $\checkmark$ \\
\hline $\begin{array}{c}\text { Ptehetep and } \\
\text { Akhethetep }\end{array}$ & 5 & Saqqara & & $\checkmark$ & & & \\
\hline $\begin{array}{c}\text { Ptehetep and } \\
\text { Akhethetep }\end{array}$ & $5^{\mathrm{t}}$ & Saqqara & $\checkmark$ & & & & $\checkmark$ \\
\hline Iasen & 5 & Giza & $\checkmark$ & & & $\checkmark$ & $\checkmark$ \\
\hline Ti & 5 & Saqqara & & & $\checkmark$ & & $\checkmark$ \\
\hline Shedu & 5 & Deshasheh & $\checkmark$ & & & & \\
\hline Neferiretenef & 5 & Saqqara & $\checkmark$ & & & & $\checkmark$ \\
\hline Vatican museum & 5 & Vatican museum & $\checkmark$ & & & & $\checkmark$ \\
\hline Ka-m-Ankh & 6 & Giza & & $\checkmark ?$ & & & $\checkmark$ \\
\hline Idout & 6 & Saqqara & $\checkmark$ & & & & $\checkmark$ \\
\hline Pepi-ankh & 6 & Meir & $\checkmark$ & & & & $\checkmark$ \\
\hline Nikauisesi & 6 & Saqqara & $\checkmark$ & & & & $\checkmark$ \\
\hline Hesi & 6 & Saqqara & & $\checkmark$ & & & $\checkmark$ \\
\hline Seankhuiptah & 6 & Saqqara & $\checkmark$ & $\checkmark$ & & & $\checkmark$ \\
\hline Mereruka & 6 & Saqqara & $\checkmark$ & $\checkmark$ & & & $\checkmark$ \\
\hline Mehu & 6 & Saqqara & $\checkmark$ & & & & $\checkmark$ \\
\hline
\end{tabular}

From Table 1: most of the scenes show the nest lies before the mongoose during its attack on the young birds. Few scenes represented the nest above it and rarely show the nest below the mongoose. If the mongoose was represented twice in the same scene, the nest would be found before and above, to give more vitality to the scene. Scenes generally represented the nest before the mongoose on the same papyrus stem or the other papyri stems in a separate scene. If the mongoose launches attack on the nest, and this act was repeatedly twice in the same scene, then the two cases are represented symmetrically. Obviously, the weak papyrus stem did not support the mongoose and the nest, in addition to this the violent movement caused by the quarrel between the mongoose (the predator) and adult birds (the protector) to defend their nest. Furthermore, not a single scene registered of a mongoose launching an attack on a nest with eggs, although eggs were among diet (Hoath: 2009: 90), and most of the Old Kingdom tombs show the mongoose on their wall decorations.

\section{Religious context}


The scenes of the papyrus thicket in the tombs of the Old Kingdom point out to a religious significance of the tomb representations because the papyrus thicket is the mythical place of the birth and upbringing of god Horus (Altenmüller, 1996: 169), although, it looks like an imitation of the true nature (Wolf, 1957: 229). The fowling scene represents the triumph of order over chaos. By bringing them down with a throwing stick, the tomb owner overcomes chaos and establishes order (Robins, 1998: 188). This maintenance of order was important within the tomb context, as the tomb owner desired a smooth transition into the afterlife. (Anthony, 2016: 54). The hunting scene in the tomb of Menna (TT 69) at Thebes for example, the son who pointed a finger to the two little predators that are about to steal the bird's eggs. Pointed fingers were a magical gesture for averting evil in ancient Egypt, and the attack on the nest may well be a reminder of the vulnerability of life (Grish and Watts, 1998: 117). Also throwing the papyrus by the deceased in the tomb of Iasen (G 2196) at Giza was connected with the god Horus which indicates his vigor and maturity and an attempt to form the thickets of papyrus to regain power (Altenmüller, 1996: 204). And that mongoose who was part of causing chaos in the marshes, thus the deceased would regain control later. This was revered by the Egyptians when several gods and goddess transformed into a mongoose, whose ability for eating snakes was highly valued. It was the sacred animal of Amun, and it was not only an animal of Atum but of Re as well, and also, of the goddess Wadjet. (Myśliwiec,2000: P. 99; Bunson, 2012: 196).

\section{Conclusion}

Maybe the word of $h t s$ is the oldest name known of mongoose dated to the $3^{\text {rd }}$ Dynasty, as a title of an official in his tomb at Saqqara (fig. 5). The repeated theme portraying the mongoose on most of the walls scenes as following; (1) a mongoose creeping on a bent papyrus. (2) attacking a nest to snatch fledglings, (3) and the parent or the adult birds preparing to defend the nest. It was common to represent him cooperating with a genet when attacking birds in the marshes, and seldom a scene represented it alone. Although the Egyptian mongoose is an earthy animal, few scenes show it on the ground climbing up a papyrus thicket (figs. 4, 18, 20, 24). Two Old Kingdom scenes show mongooses being held by tails (figs. 22-23), and one scene from the Middle Kingdom, shows it Attached to a leash (fig. 24), which indicates that the ancient Egyptian might have tamed it.

Birds were the only representation that came under his attack, Although the variant diet of the mongoose, with no specific bird favored by it. Noteworthy, there was only one scene representing a mongoose eating a fish (fig18). Furthermore, the Egyptian mongoose is strictly an earthy animal, and the pied kingfisher, which was repeatedly depicted defending its nest, places its eggs in a deep hole on the riverbanks and canals. Besides, a papyrus stem does not support a nest of birds (fig. $25)$. Everything suggests that these scenes are fictional. Therefore, the composition of the papyrus thicket was not a reflection of the real wildlife but, a fancy composition suitable for the religious and the realm of the underworld. These scenes are all found in a funerary context and therefore one expects them to have a religious dimension as well.

\section{References}

Altenmüller, H., (1996). Le Maître du Tombeau en tant qu'Horus fils d'Osiris, Revue d'Egyptologie et des Civilisations Africaines, Ankh 4/5, 196-213.

Anthony, F, B., (2016. Foreigners in Ancient Egyptian Theban Tomb Paintings from the Early Eighteenth Dynasty, London, Bloomsbury.

Anderson, J., (1898). Zoology of Egypt, vol. I, London, Wheldon \& Wesley, LTD, (1902) Zoology of Egypt: Mammalia, London, Hugh Rees, LTD.

Arnold, D., (1995). An Egyptian Bestiary, New York, The Metropolitan Museum of Art Bulletin.

Angelici, F, M. (2016) Problematic Wildlife, New York, Springer

Bailleul-Lesuer, R (2012). Between Heaven and Earth (edited), Chicago, the Oriental Institute of the University of Chicago.

Bertrand, J., (1982). Essai de Classification et Datation des Scarabées Menkhéperreê, Éditions Universitaires Fribourg Suisse, Vandenhoeck \& Ruprecht Göttingen.

Bissing, F.W.F, (1955). Chambre des Trois Saisons du Sanctuaire Solaire du Roi Rathousir (V dynastie) À Abousir, Annales du service des antiquités de l'Égypte (ASAE/53.2), 319-338.

Binder, S., (2000). The Tomb Owner Fishing and Fowling, in Egyptian Art, Giza, Prism Publication Office.

Blackman, A.M and Apted, M.R (1953a). The Rock tomb of Meir V. London. Egypt Exploration Society.

Blackmanm, A.M and Apted, M.R (1953b). The Rock tomb of Meir VI, London Egypt Exploration Society. 
Brunner-Traut, E, (2001). Ichneumon, in the Oxford Encyclopedia of Ancient Egypt, vol. II, New York, Oxford University Press Inc.

Brunner-Traut, E., (1965). Spitzmaus und Ichneumon als Tiere des Sonnengottes, Göttingen, Vandenhoeck \& Ruprecht.

Brovarsky, E., (2000). The Senedjemib Complex, Part I, Boston, Museum of Fine Arts.

Bunson, M.R (2012). Encyclopedia of Ancient Egypt (3rd ed.), New York, Facts On File.

Budge, E.A.W, (1920). Egyptian Hieroglyphic Dictionary, Vol. I, London, Harrison and Sons.

Černy, J., (1976), Coptic Etymological Dictionary, London, Cambridge University press.

Chaban M. and Quibell J. E. (1902). Sur une Nécropole de la VI Dynastie A Koçeir El-Amarna, Annales $d u$ service des antiquités de l'Égypte 3, 250-258.

Collins, B., (2002). A History of the Animal Worlds in the Ancient Near East, Boston, Brill.

Cooney, J. D, (1965). Pharaoh's Rat, The Bulletin of the Cleveland Museum of Art, 52(8), 101-105.

Daressy, M.G, (1901). Rapport sur la Trouvaille de Hatiay, Annales du service des antiquités de l'Égypte, ASAE/2, 8-9.

Davies, N. De G., (1900a). The Mastaba of Ptahhetep and Akhethetep at Saqqareh, vol. I, London, Egypt exploration Fund.

Davies, N. De G., (1901b) The Mastaba of Ptahhetep and Akhethetep at Saqqara, Part II, London, Egypt exploration Fund.

Davies, N. De G., (1901). The Rock Tomb of Sheikh Said, London, Egypt Exploration Fund

David, R., (2003). Handbook to life in Ancient Egypt, New York, Facts On File, Inc.

Description de l' Égypte, (1809) vol. 1, Paris, De l'Imprimerie Impériale.

Desroches-Noblecourt, C., (1962) Egyptian Wall Paintings from Tombs and Temples, New York, the New American Library of world literature, INC

Erman, A, and Grapow, H., (1971) Wörterbuch der Aegyptischen Sprache I, Berlin, Akademie-Verlag.

Erman, A, and Grapow, H., (1971). Wörterbuch der Aegyptischen Sprache III, Berlin, AkademieVerlag.

Evans, L. (2000) Animals in the Domestic Environment, in Egyptian Art, Prism Publication Office, Giza, Egypt.

Evans, L. (2007). Fighting kites: Behavior as a key to species identity in wall scenes, Journal of Egyptian Archeology, 93, 245-270.

Evans, L. (2010). Otter or Mongoose? Chewing over the evidence in wall Scenes, Conseil Suprême des Antiquités de l'Égypte, 1190-130.

Evans, L. (2015). Animal Behavior in Egyptian Art: A Brief Overview in Proceeding of the Tenth international Congress of Egyptologists, Vol. II, Leuven-ParisBristol, CT, Peeters/
Evans, L. (2016). Beasts and Beliefs at Beni Hassan: A Preliminary Report, Journal of the American Research Center in Egypt, (JARCE/ 52). 219-229.

Faulkner, R, O., (1964). A Concise Dictionary of Middle Egyptian, Oxford, Griffith Institute University Press.

Faulkner, R, O. (1997). The Ancient Egyptian Coffin Texts, Vol. II, Warminster, Aris \& Phillips Ltd.

Gardiner, A.H. (1938). The Mansion of Life and the Master of the King's Largess, Journal of Egyptian Archaeology, 24(1-2), 81-93.

Gardiner, A.H. (2007). Egyptian Grammar, Oxford Griffith Institute.

Girsh, B., and Watts, E. W., (1998) Art of Ancient Egypt, New York, Metropolitan Museum of Art.

Hannig, R., (1997). Die Sprache der Pharaonen; Großes Handwörterbuch, Deutsch-Ägyptisch, Band 64, Mainz, Verlag Philipp Von Zabern.

Hannig, R., (2000). Die Sprache der Pharaonen; Großes Handwörterbuch, Deutsch-Ägyptisch, Band 86, Mainz, Verlag Philipp Von Zabern.

Hart, G, (2005). The Routledge Dictionary of Egyptian Gods and Goddesses. New York and New York, Routledge

Hassan, S., (1943). Excavations at Giza, vol. IV, Cairo, Government Press.

Hassan, S., (1950). Excavations at Giza, vol. VI-part III, Cairo, Government Press.

Hayes, W. C., (1951). Inscriptions from the Palace of Amenhotep III. Journal of Near Eastern Studies, 10(3), 35-56.

Helck, W, and Otto, E., (1980) Lexikon der ÄGyptologie, III, Wiesbaden, Otto Harrassowitz.

Hepper, F.N, (1990) pharaoh's Flowers, London, HMSO.

Hinton H.E and Dunn, A. M (1967). Mongooses, Their Natural History and Behavior, Los Angeles, University of California Press.

Houlihan, P.F, (1986) The Birds of Ancient Egypt, Cairo. the American University in Cairo Press.

Houlihan, P.F. (1996). The Animal world of the Pharaohs, Cairo, the American University in Cairo Press.

Hoath, R., (2009). A Field Guide to the Mammals of Egypt, The Cairo-New York, American University of Cairo Press.

Jackson, L., (2018) Sekhmet \& Bastet the Feline powers of Egypt, London, BM Avalonia.

Junker, J., (1940). Giza IV, Die Mastaba des KAjmanh (Kai-em-anch), Wien und Leipzig, Hölder-PichlerTempsky A.G.

Kanawati, N. and Abder-Razig, M, (1998). The Teti Cemetery at Saqqara, The Tombs of Neferseshemre and Seankhuiptah. vol. III, Warminster, Aris and Phillips Ltd.

Kanawati, N and Abder-Raziq, M (2000). The Teti Cemetery at Saqqara VI, The of Nikauisesi, Warminster, Aris and Phillips Ltd. 
Kanawati, N. \& Woods, A (2009). Artists in the Old Kingdom, Cairo, Supreme Council of Antiquities.

Kantor, H. J., (1999) - Plant Ornament its Origin and Development in the Ancient Near East (PhD), Chicago, Illinoi, Oriental Institute, University of Chicago.

Lashine, M., (2011). Narrative in Old kingdom wall scenes: The Progress through Space and Time. Bulletin of the Australian Centre for Egyptology, 22 (BACE).

Lewis, S. and Llewellyn-jones, L., (2018). The Culture of Animals in Antiquity, London and New York, Routledge.

Lowe, Brenda (2004). The Domestic Cat in Egyptian Tomb Painting, The Ostracon, vol. 16, no.1

Macramallah, R (1935). Le Mastaba D'Idout, Le Caire, Imprimerie De L'Institut Français D’Archéologie Orientale.

Malek, j., (2000). Egyptian Art, London, Phaidon.

Manniche, L., (1989) The Tombs of the Nobles at Luxor, Cairo, the American University in Cairo Press.

Murray, M.A \& Loat, L (1905). Saqqara Mastaba, Part I, London, British School of Archeology in Egypt.

Murray, M. A., and Sethe, K., (1937). Saqqara Mastabas, part II, London, British School of Archeology in Egypt.

Myśliwiec, K., (2000). The Twilight of Ancient Egypt: First Millennium B.C.E., London, Cornell University Press.

Newberry, P. E, (1893a). Beni Hasan I, London, Kegan Paul, Trench, Trübner \& Co., Ltd,

Newberry, P. E. (1893b). Beni Hasan II, London, Kegan Paul, Trench, Trübner \& Co., Ltd,

Nicholson, P.T, and Shaw, I, (2000). Ancient Egyptian Materials and Technology, London, Cambridge University Press

Petrie, W. M.F., (1898). Deshasheh, London, Egypt exploration Fund

Petrie, W. M.F. (1901). The Royal Tombs of the Earliest Dynasties, part II, London, Egypt Exploration Fund.

Petrie, W. M.F. (1920). Prehistoric Egypt, British school of Archeology in Egypt, London.

Pinch G., (2002). Handbook of Egyptian Mythology, Oxford, ABC-CLIO

Porter, B, and Moss, R.L.B (1968). Topographical Bibliography of Ancient Egyptian Hieroglyphic Texts, Reliefs, and Paintings, IV, Oxford, Clarendon Press.

Remler, P. (2006). Egyptian Mythology A to Z, New York, Facts On File.

Rice, M., (2006). Swifter than the Arrow; The Golden Hunting Hounds of ancient Egypt, New York, I.B. Tauris.
Roeder, G., (1936). Das Ichneumon in der altägyptischen Religion und Kunst. in Egyptian Religion 4, New York, Alma Egan Hyatt Foundation.

Robins, G., (1998). Women in Ancient Egypt, London, British Museum Press.

Säve-Söderbergh, T., (1957). Four Eighteenth Dynasty Tombs, Oxford, Griffith Institute.

Schürmann, W., (1983). Die Relief aus dem Grab des Pyramidenvorstehers Li-Nefert, Karlsruhe, Badisches Landesmuseum.

Simpson, W. K., (1976). The Mastabas of Qar and Idu, Boston, Museum of Fine Arts.

Simpson, W. K., (1980). Mastabas of the Western Cemetery: part I, Boston, The Museum of fine Arts.

Smith, W. S., (1946). A History of Egyptian Sculpture and Painting in the Old Kingdom, The Oxford University Press, London.

Smith, M., (2001). Papyrus, in The Oxford Encyclopedia of Ancient Egypt, vol. III, New York, Oxford University Press.

Strandberg, A (2009). The Gazelle in Ancient Egyptian Art, $(\mathrm{PhD})$, Sweden Uppsala Universitet

The Sakkarah Expedition, I (1938). Chicago, The University of Chicago Press.

Tristant, Y., and Ellen, R, E.M., (2017). Animals in ancient Egypt: "Roles in life and death" in Death is Only the Beginning, Oxford, Aris and Phillips Ltd.

Vernus, P. and Yoyotte, J., (2005). Besttiaire, des Pharaons, Paris, Perrin

Wassell, B., (1991). Ancient Egyptian fauna: a lexicographical study., Durham theses, Durham University. Available at Durham E-Theses Online: http://etheses.dur.ac.uk/1152/

Waugh, R. L., (1995). The Eye and Man in Ancient Egypt, Oostende, Belgium: Wayenborgh

Wendorf, F and Schild, R. et al. (2001). the Archaeology of Nabta Playa, vol. I, New York, Springer Scince+Business Media, LLC,

Wild, H., (1953). Le Tombeau de Ti II, Le Caire, Imprimerie de L'Institut Français D’Archéologie Orientale (IFAO/65).

Wild, H. (1953). Le Tombeau De Ti, I, Le Caire, Imprimerie De L'Institut Français D'Archéologie Orientale.

Wilkinson, G., (1871). Popular Account of the Ancient Egyptian, vol. 1, London, John Murray

Wolf, Walther, (1957). Die Kunst Aegyptens, Stutgart, W. Kohlhammer Verlag.

Louvre Museum (accessed 20/5/2020)

https://www.louvre.fr/en/oeuvre-notices/scene-nilemarshes 


\section{Figures}

Fig.1: A predynastic ware with the would-be Egyptian mongoose

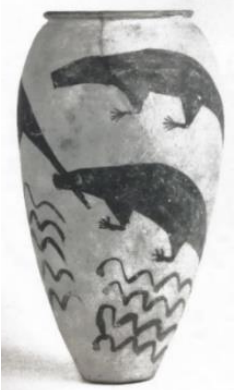

After, Houlihan, 1996: fig. 85

Fig. 3: A cylinder Jar with a mongoose

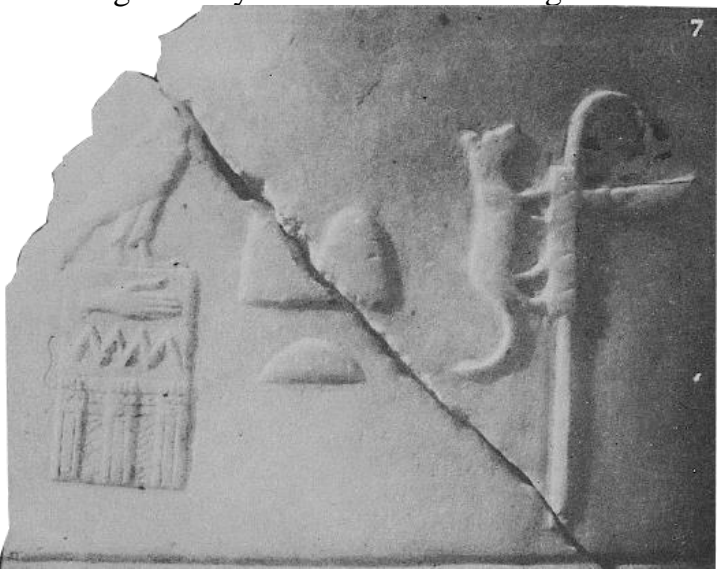

after, Petrie, 1901: pl.VII.7

fig.5A: mongoose as an official title
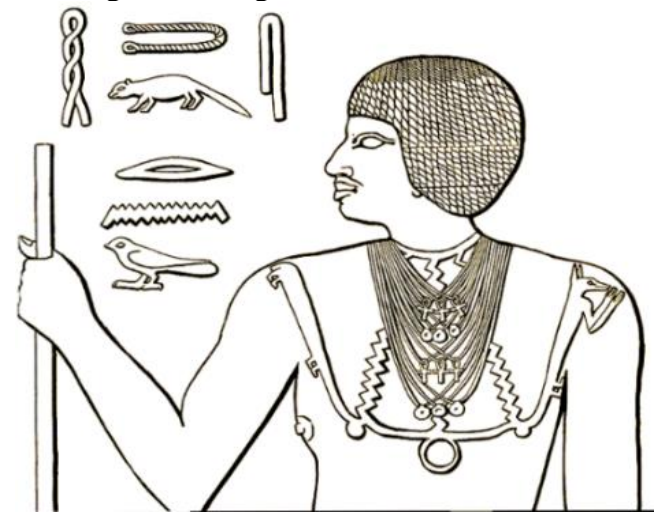

After, Murray, and Sethe: Pls. I, II fig. 6: An Egyptian mongoose

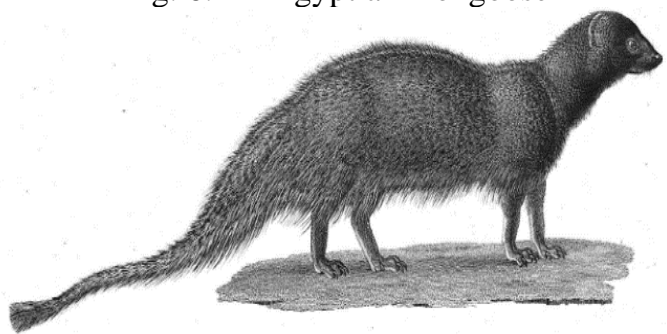

After, Description de l' Égypte, vol. 1, pl. 6
Fig. 2: A predynastic ware with the would-be Egyptian mongoose

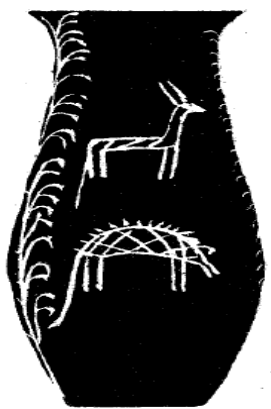

After, Petrie, 1920: Pl. XVIII

fig. 4: A mongoose on a stone block from Abusir

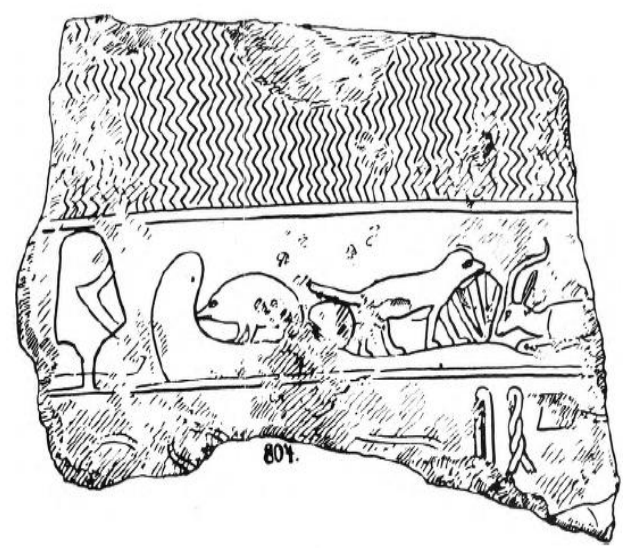

After, Bissing, 1955: pl. XXIII

fig. 5B: Amenhotep III personified as a mongoose

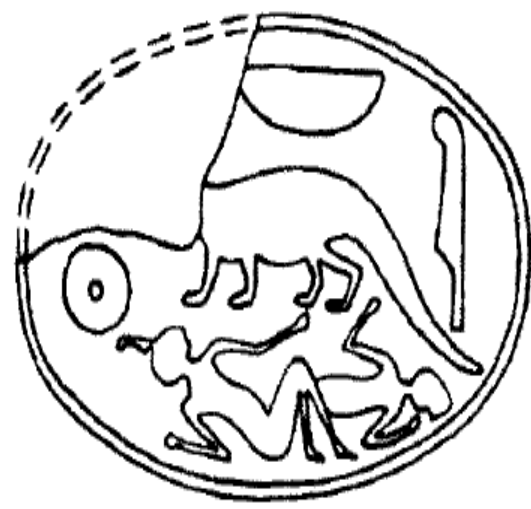

After, Hayes, 1951: fig. 31 no. 34

fig. 7: A detail from a papyrus thicket

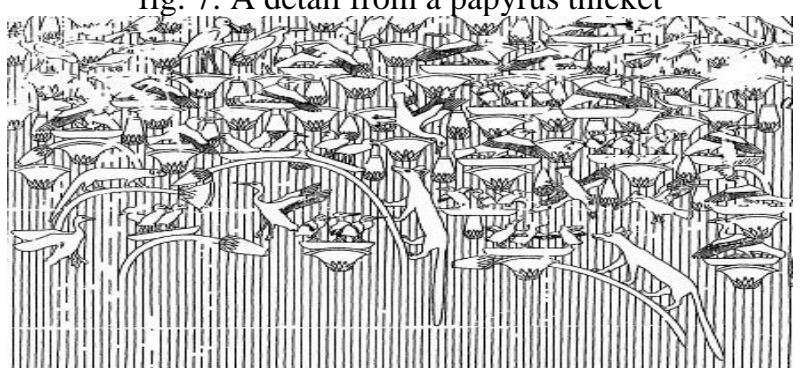

After, Epron-wild, 1953: pl. 119 
Fig. 8: The mongooses preyed young birds

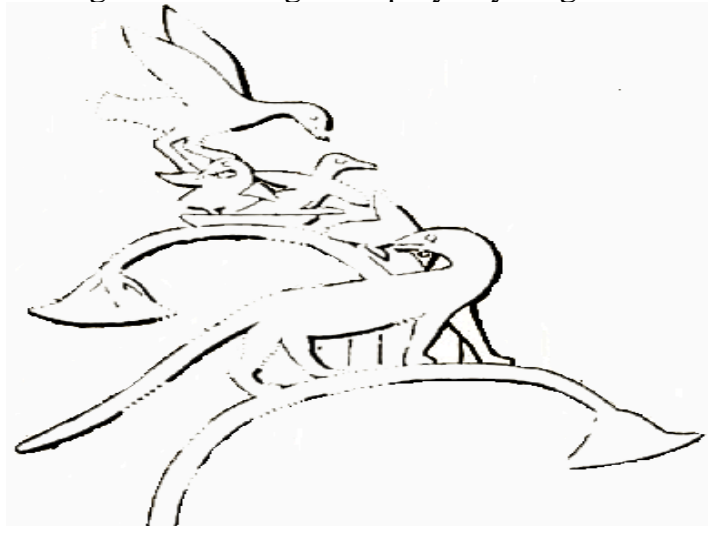

After, Davies, 1901, pl. XIII

Figs. 10: A mongoose attack on the papyrus thicket

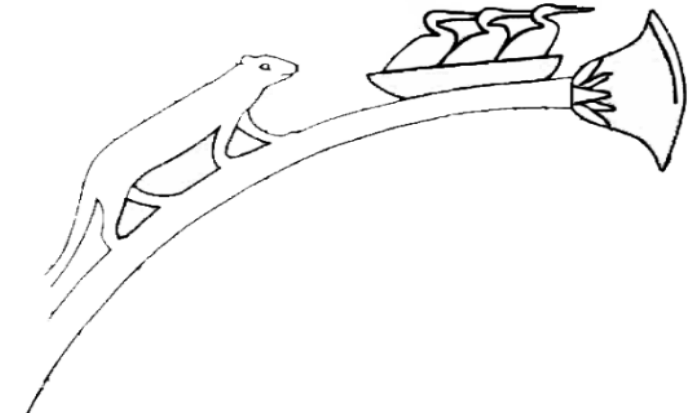

After, Simpson, 1980: Fig. 30

Fg.12: mongooses attack young birds

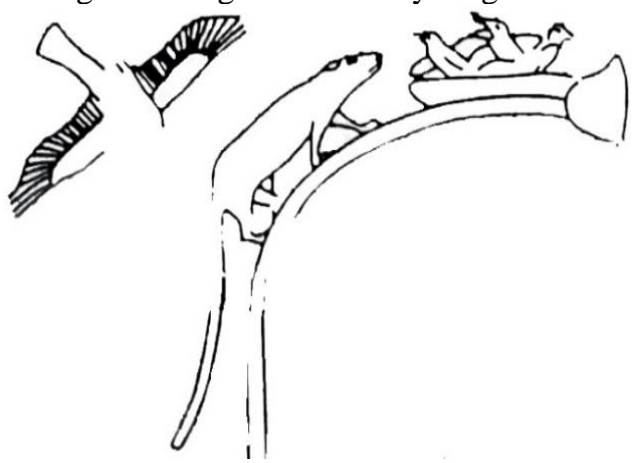

After, Binder, 2000: fig. 11. 7

Fig.14: Birds defended their nests from mongoose's attack.

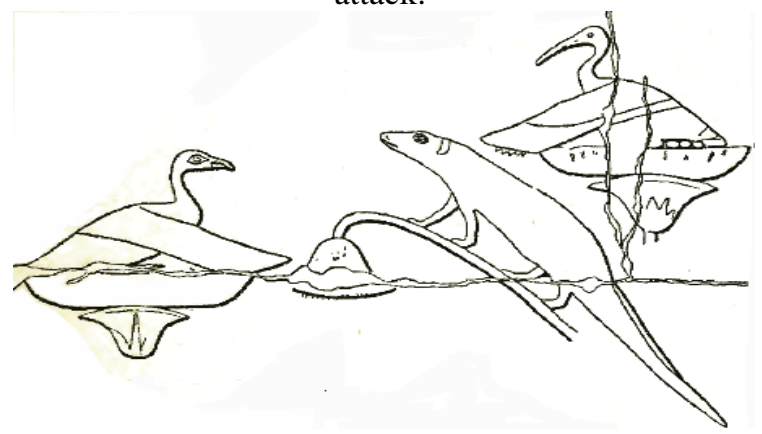

After, Macramallah,1935: pl. VII

Fig. 16: Adult birds protected their fledglings from mongoose's attack.
Fig. 9: The mongooses preyed young birds

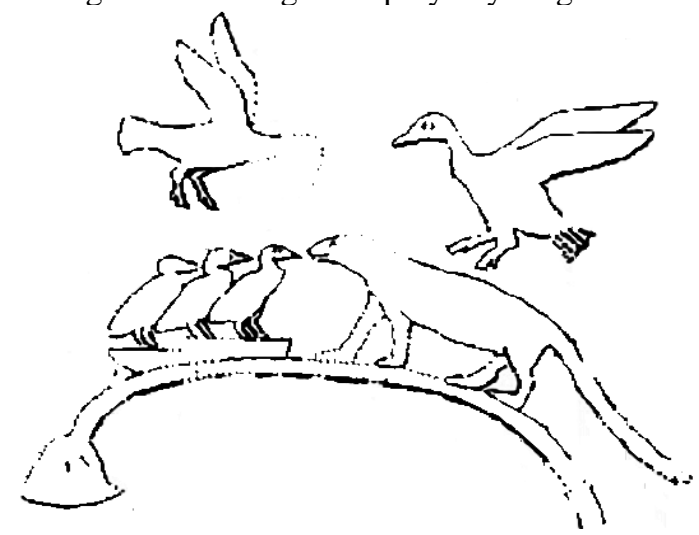

After, Davies, 1901, pl. XIV

Fig. 11: A mongoose attack on the papyrus thicket

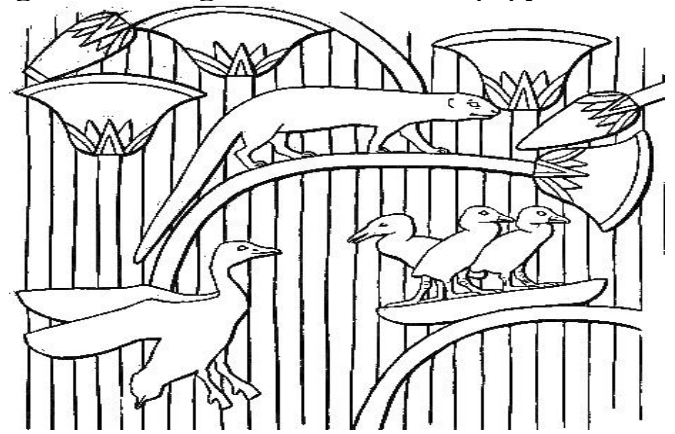

After, Murray and Sethe, 1937: pl. II

Fig. 13: mongooses and a cat attack young bird

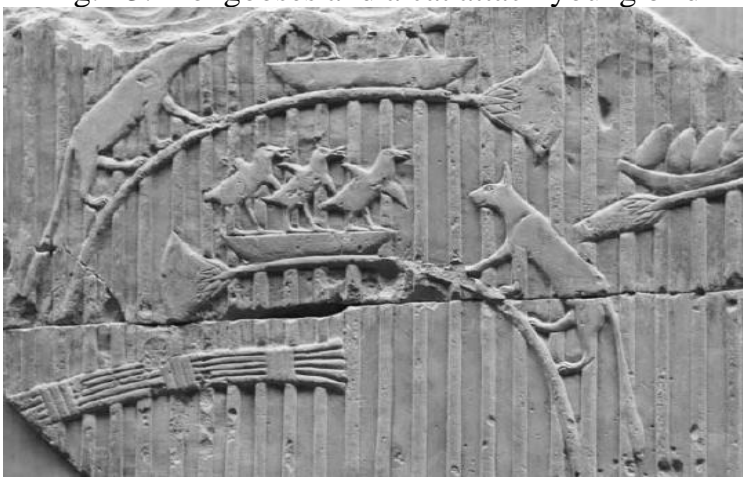

After, Wolf, 1957: fig. 68

Fig.15: Birds defended their nests from mongoose's attack.

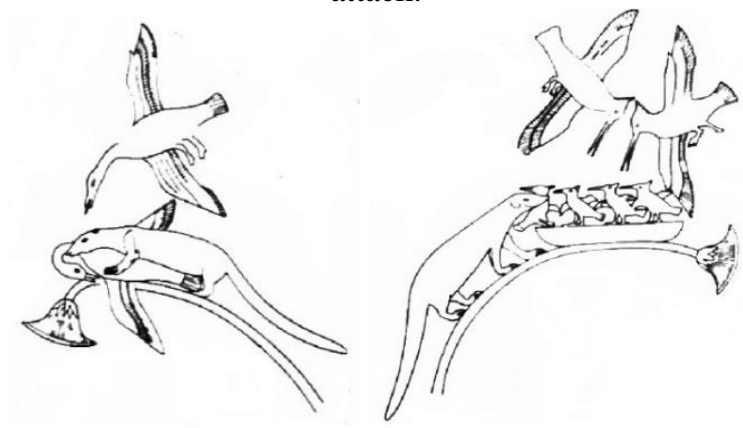

After, Kanawati and Abder-Raziq, 2000: pl. 50

Fig. 17: Adult birds protected their fledglings from mongoose's attack. 


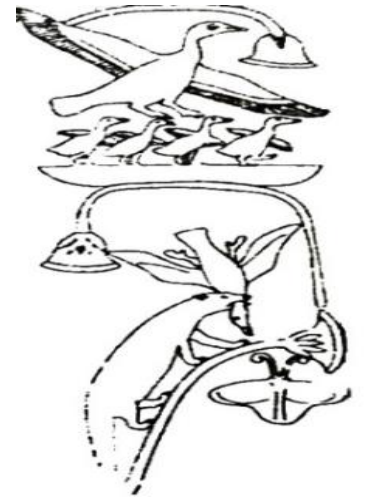

After, Binder, 2000: fig. 11.17

Fig. 18: mongoose eating a fish

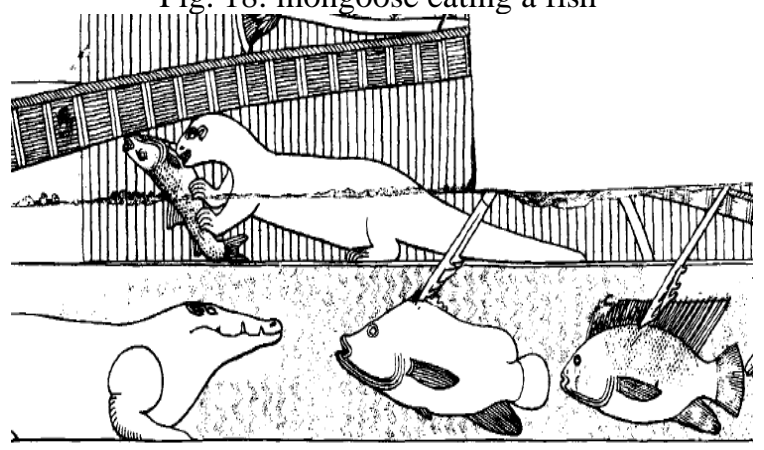

After, The Sakkarah Expedition, 1938: pl. 128

Fig.20: mongoose in the hunting scene

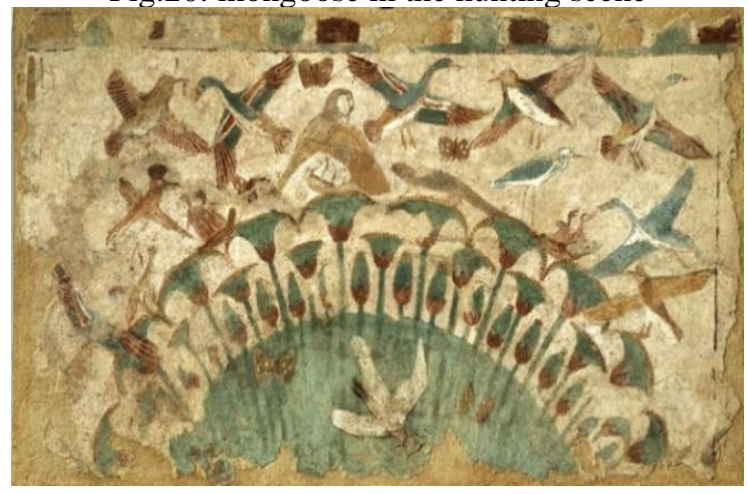

CMusée du Louvre

Figs.22-23: Holding mongoose by tail

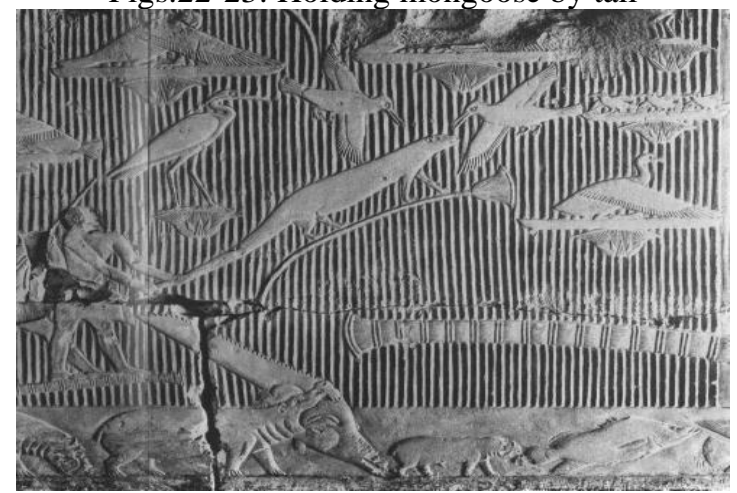

After, Houlihan, 1996, pl. X

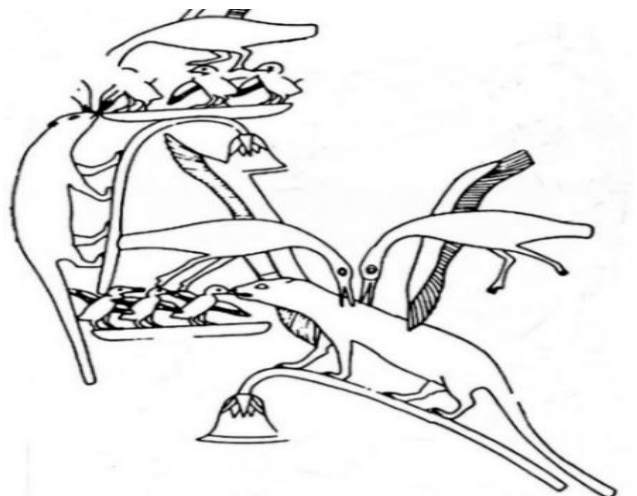

After, Kanawati and Abder-Raziq 1998: pl. 76

Fig. 19: mongoose preparing to attack

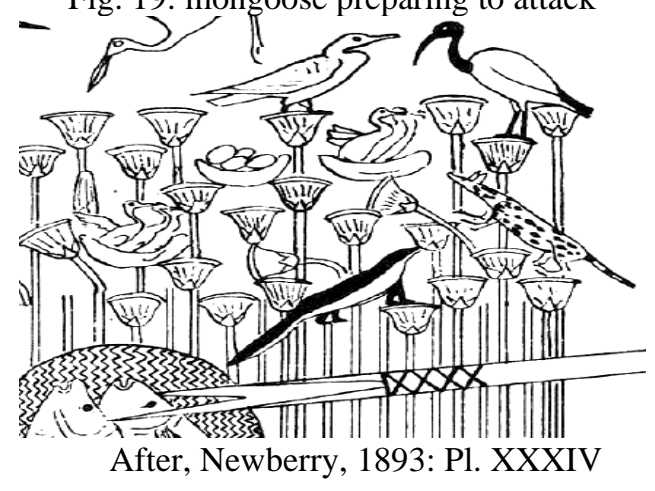

fig. 21: threating birds' nest

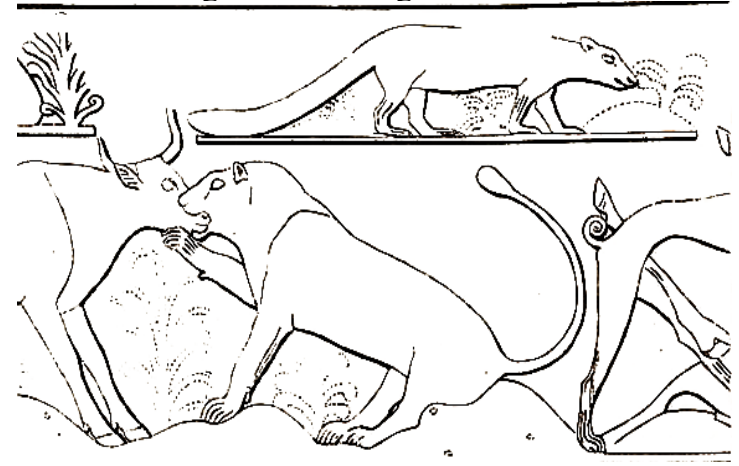

After, Davies, 1900: Pl. XXII

Figs.22-23: Holding mongoose by tail

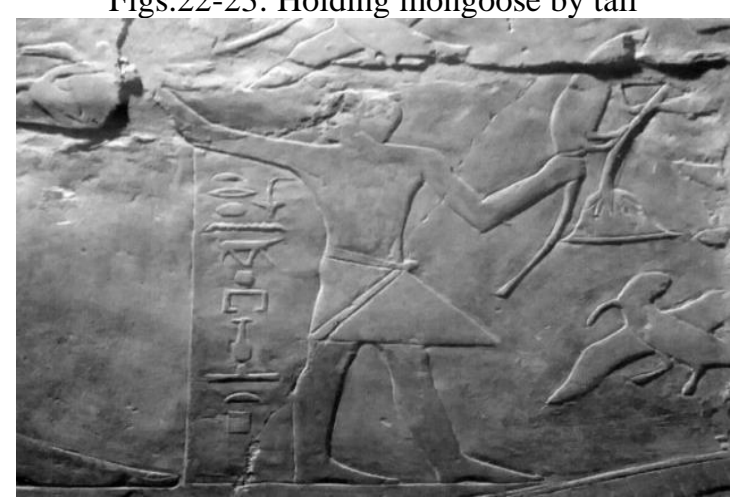

After, Kanawati \& wood, 2009: pl. 146 
Fig. 24: a man led a mongoose by a leash.

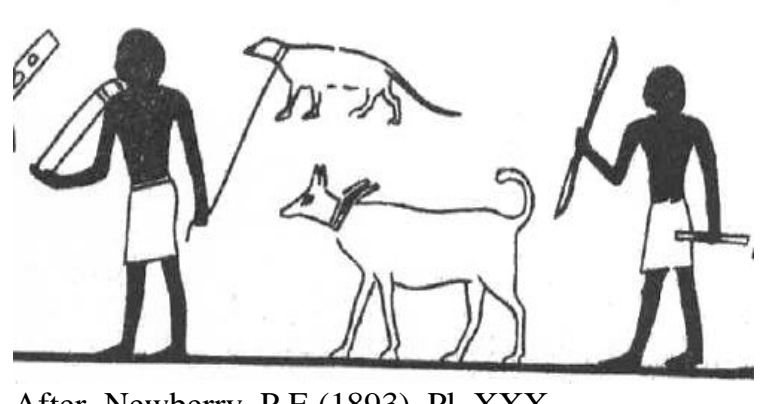

After, Newberry, P.E (1893), Pl. XXX fig. 25: a nest over papyrus umbel

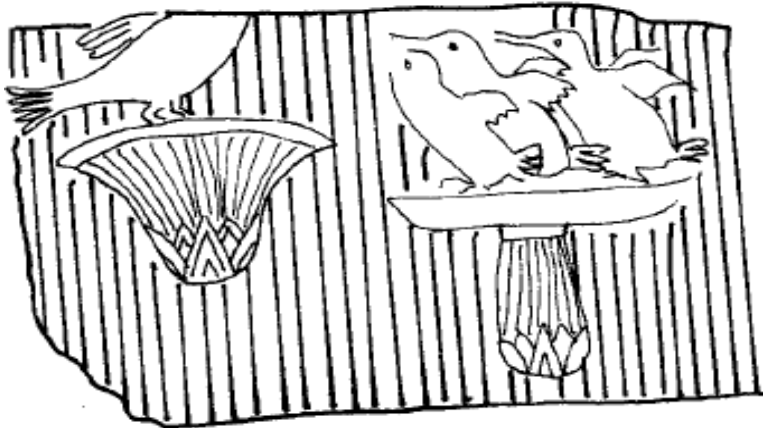

After, Kantor, 1999: fig. II.93 